\title{
Nutraceuticals as Functional Foods
}

\author{
Somya Gupta*, Nayyar Parvez and Pramod Kumar Sharma
}

\begin{abstract}
Department of Pharmacy, School of Medical and Allied Sciences, Galgotias University, Greater Noida, U.P. 203201, India
\end{abstract}

\begin{abstract}
Nutraceuticals are considered to be fortified or enriched foods providing all the essential nutrients required for maintaining the optimal health. A numerous studies have suggested the potential association of nutraceuticals with diet and health. This article gives a brief review on the classification of nutraceuticals on the basis of the availability of the nutraceutical from the natural sources which is further being processed and proving its medical health benefits in the market. The review also summarizes about the functional nutraceuticals acting as dietary supplements, suggested to have the capacity to significantly contribute to the modulation of the complex mechanisms of disease pathology with a view being that they may be essential in optimizing in vivo defences and help in maintaining wellness. Nonetheless, several more clinical and biological studies are needed to support guidelines for the intake of nutraceutical for the prevention and treatment in specific diseases and its medical benefits.
\end{abstract}

Keywords: Nutraceutical, Functional foods, Disease, Fortified foods, Health benefits.

\section{INTRODUCTION}

The word nutraceutical was coined by the Foundation for Innovation in Medicine (New York, US). As the name implies, nutraceutical are the product used parallel, in the same manner as pharmaceutical is being used. Nutraceutical can be defined as any substance that may be considered a food or part of food and provides medical or health benefit including the prevention and treatment of disease. The foundation elaborated the growing field of biomedical research mainly focussed on isolation of nutrients/ bioactive compounds from the natural products, genetically modification of dietary supplements/ diets, processed foods (such as soups, beverages) and herbal products [1]. In the food industry the major progressive segment is nutraceutical due to the advanced food technologies merged with peculiar properties of nutrients leads to the creation of fortified nutritive products [2]. So, in the recent years these products have drawn great attention due to its high potential that have been proven to help prevent or cure diseases [3]. As increasing, consumer health care has been centre of attraction for which various extensive researches have been directed towards the clinics and studies on nutrients and genomics, to meet the consumer needs [1]. So these nutraceutical aimed primarily maintaining health as according to the U.S. Food and Drug Administration (FDA) defines as "formulated to be consumed or administered enterally under the supervision of a physician and which is intended for the specific dietary management of a

*Address correspondence to this author at the Department of Pharmacy, School of Medical and Allied Sciences, Galgotias University, Gautam Buddh Nagar, Greater Noida (U.P.) 203201, India;

E-mail: angelsomya@gmail.com disease or condition for which distinctive nutritional requirements, on the basis of recognized scientific principles, are established by medical evaluation" [4].

However, nutraceuticals or pharmaconutrient are exactly not drugs, but surely they can be referred as nutrient or dietary supplement which defends, supports, and normalizes physiologic or metabolic function, also having the ability to increase the effect, antagonize, or otherwise modify physiologic or metabolic functions. Nutraceutical may comprise of single natural nutrient in the form of tablet or powder, essentially not a complete food neither a drug [5].

\section{FUNCTIONAL FOODS}

Functional foods denotes to a new and challenging concept which is slightly different from the nutraceutical so these can be regarded as food products or ingredient, consumed as a part of usual diet providing the beneficial effects beyond the basic nutrients that traditionally it contains are called as functional foods [6]. Such as nuts, garlic, green tea.

Functional foods provide carbohydrates, proteins, fat and vitamins to the body in required amount for healthy survival of the body. When functional food contributes in the prevention and treatment of disease then it is referred to as nutraceuticals [7]. Otherwise the difference between the functional food and nutraceutical is not exactly clear but the main difference is the form in which they are consumed that is the nutraceutical are ingested in the form of tablet, capsules or pills while functional foods are ingested as "ordinary foods". When phytochemical is added to the food formulation then they are considered as functional foods and when phytochemical is included in the 




Figure 1: Some examples of functional food products exerting the biological activities.

capsule or any dosage forms then they are established as nutraceutical [8].

Few examples of functional foods are represented in Figure 1.

\section{CLASSIFICATION OF NUTRACEUTICALS}

There is large number of compounds; therefore it is difficult to classify all types of nutraceuticals. Hence, an approach is made for classification of nutraceuticals on the basis of nutraceuticals available in the market as shown on Figure 2 [9, 10].

Plant-derived foods have the capacity to reduce the risk of chronic diseases. Since the phytochemical present, found to have low potency as compared to the pharmaceutical drugs but when ingested regularly they are expected to exert some favourable influences on the pathophysiological function of the body [8]. There are some examples of bioactive compounds present in

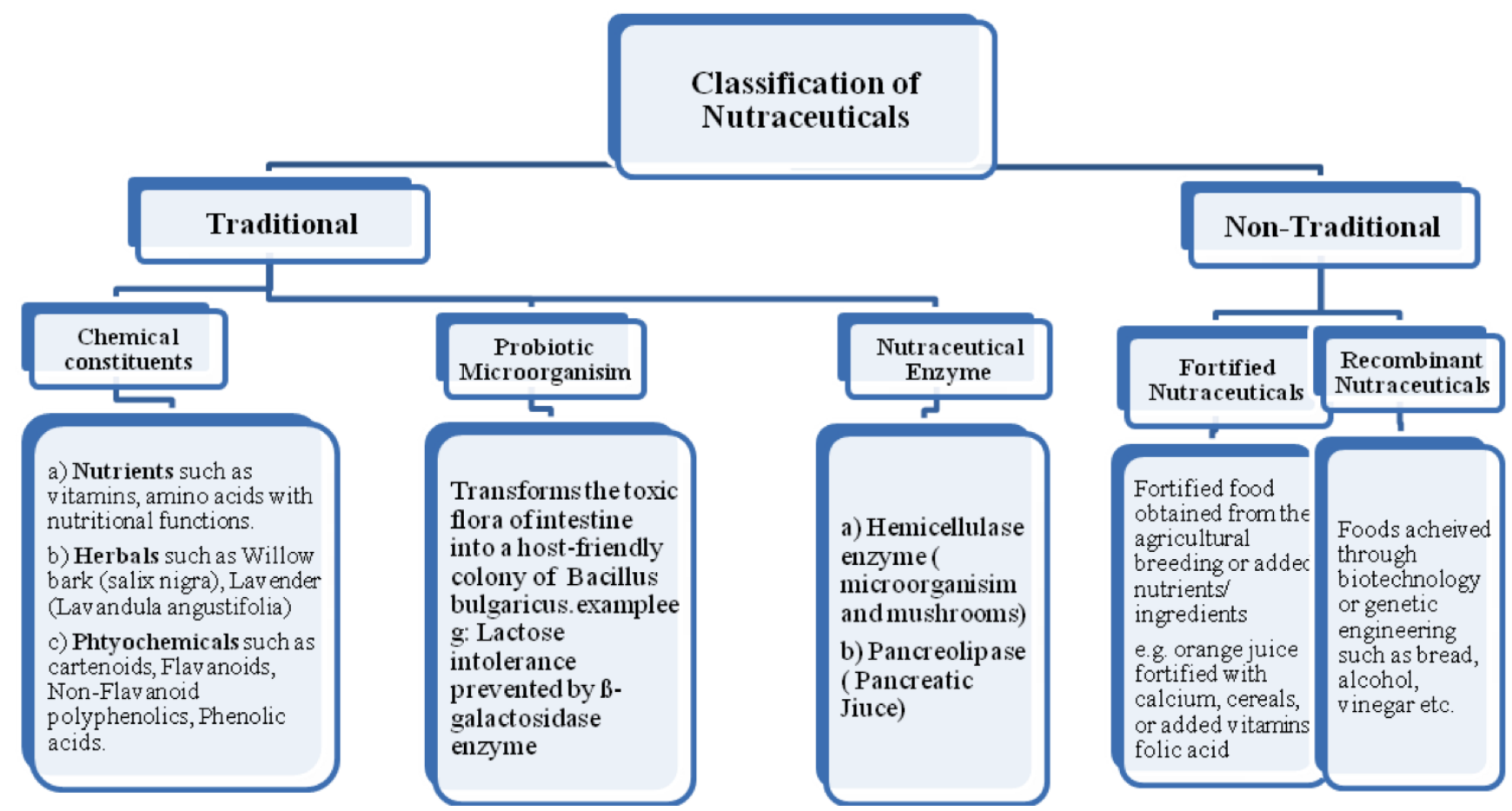

Figure 2: Tabular representation of classification of nutraceuticals. 
Table 1: Bioactive Compound Based Nutraceuticals Possessing Health Benefits

\begin{tabular}{|c|c|c|c|c|}
\hline S. No. & Nutraceutical & Natural sources & Health benefits & References \\
\hline 2. & $\begin{array}{l}\text { Milk-lipids (triglycerides, saturated fatty } \\
\text { acids) }\end{array}$ & Milk & Anti-inflammatory, immunosupressive & [12] \\
\hline 3. & Squalene & Vegetable oils & $\begin{array}{l}\text { Lowering cholesterol and anti-cancer } \\
\text { activity }\end{array}$ & [13] \\
\hline 5. & Gangliosides & Dairy products (Milk) & $\begin{array}{l}\text { Protect against pathogens and prebiotic } \\
\text { activity }\end{array}$ & [15] \\
\hline 6. & Selenopeptides & Nuts & Anti-oxidant, anti-cancer, heart disease & {$[16]$} \\
\hline 7. & Peptides & Fishes & $\begin{array}{c}\text { Anti-coagulant, antihypertensive, anti- } \\
\text { oxidant }\end{array}$ & [17] \\
\hline 10. & Cyclopeptides & Cow-cockle seed & Estrogen activity in-vivo & [19] \\
\hline 11. & Vitamin B1 and Vitamin B2 & Mushrooms & Anti-oxidant & [20] \\
\hline 12. & Tocopherols(Vitamin E) & $\begin{array}{l}\text { Vegetable and vegetable } \\
\text { oils }\end{array}$ & $\begin{array}{l}\text { Anti-tumor, anti-oxidant, treatment of } \\
\text { cardiovascular diseases }\end{array}$ & {$[21,22]$} \\
\hline 13. & Vitamin U (S-methyl-L-methionine) & Centella asiatica & Wound Healing & [23] \\
\hline 14. & Vitamin C (L-ascorbic acid) & Fruits & Anti-oxidant & [24] \\
\hline 15. & $\begin{array}{c}\text { Glycosides (glycyrrhetic acid, } \\
\text { Glycyrrzhin) }\end{array}$ & Plants & $\begin{array}{l}\text { Diuretic, anti-cancer, anti-oxidant } \\
\text { properties }\end{array}$ & [25] \\
\hline 18. & Flavanoids & Citrus Peel & Anti-cancer, anti-inflammatory & [28] \\
\hline 19. & Phenolics & Pepper & Anti-oxidant & [29] \\
\hline 20. & Phenolics & Vanilla plantfolia & Anti-oxidant & {$[30]$} \\
\hline 21. & Catechins & Green tea & Anti-oxidant & [31] \\
\hline 22. & Flavanoids and Phenolic acids & Chinese Herbal tea & Anti-oxidant & [32] \\
\hline 23. & Lignans & $\begin{array}{l}\text { Myristica fragrans } \\
\text { (nutmeg) }\end{array}$ & Anti-cancer & [33] \\
\hline 24. & Catecholamines & Banana Peel & Anti-oxidant & [34] \\
\hline 25. & Anthocyanins & Fruit and tubers & Anti-oxidant & [35] \\
\hline 26. & Curcuminoids & Curcuma longa & Anti-oxidant & [36] \\
\hline 27. & Rutin & Buckwheat & Anti-oxidant & [18] \\
\hline 28. & Capsaicinoids & Pepper & $\begin{array}{c}\text { Anti-inflammatory, anti-tumour, anti- } \\
\text { oxidant }\end{array}$ & [37] \\
\hline 29. & Sulforaphane & Crucifer vegetables & Anti-cancer & [38] \\
\hline 30. & Monacolins & Rice & $\begin{array}{l}\text { Decreasing cholesterol level, anti- } \\
\text { carcinogenic }\end{array}$ & [39] \\
\hline
\end{tabular}


the natural matrices such as lipids, proteins, vitamins, glycosides etc. exerting possible health benefits are utilized as nutraceuticals as shown in Table 1.

\section{NUTRACEUTICALS AND DISEASES}

Many of the natural bioactive compounds showed their beneficial properties [40] meanwhile the researchers also manifested that nutraceuticals found to have possible health benefits and utilized in treatment of several diseases such as diabetes, bone diseases, cancer [41]. Here are some nutraceuticals summarized below showing its benefits against diseases.

\section{a. Cancer}

From the extensive research revealed that chronic inflammation or diseases can be suppress by the use of nutraceuticals metabolites derived from fruits, vegetables, vitamins, spices, legumes etc. which have proven successfully in regulating tumour metabolism and growth. Vitamins also play a major role in cancer prevention and treatment by DNA methylation and DNA synthesis. However, due to low bioavailability in-vivo limits its use in treatment of cancer but by the use of nanotechnology several nutraceuticals such as catechins, curcumin, polyphenol green tea, quercetin can be manifested in nanoprevention and nanochemotherapy resulting in enhanced bioavailability of the administered nutraceuticals [42]. For eg. Ursolic acid is poorly water soluble natural product, thus its bioavailability and stability is enhanced by administering in the form of ursolic acid phospholopid nanopowders [43].

\section{b. Dry Eye Disease}

Major cause of dry eye disesase is hyperlipidemia and a diet low in omega- 3 fatty acids. The studies have profound that oral supplementation with antioxidants, omega-3 (e.g. fish oil and linseed oil) and omega-6 (e.g. evening primrose oil) fatty acids with lesser benefit. However, clinical trials looked upon the effectiveness of nutritional supplementation with omega fatty acids and antioxidants alone or in combination and omega-lipid-based dietary nutraceutical reported better comfort in dry eye disease and had improved tear volume and tear clearance [44].

\section{c. Diabetes}

Researchers have also focussed on the potential effects of the citrus fruits in the context of beneficial management of diabetes. Citrus fruits not only provide vitamins, pectins, minerals and dietary fibres rather they also constitute active phytochemicals such as phenolic acids, flavanoids, flavaones, flavanol etc. they have been widely used in the improvement of health due to its biological properties such as anti-oxidant, anti-inflammatory, inhibition of blood clots. Thus, unlike citrus fruits many other nutraceuticals [45] such as phenolic acids, flavonoids, stilbenes, lignans and polymeric lignans have potential efficacies in preventing and allevation of metabolic disorder and complications induced by diabetes [46]. Thus, offering various unique opportunities in the risk management of diabetes [45].

\section{d. Cardiovascular Diseases}

Nutraceutical potential of flavanoids for the management of cardiovascular disease. As flavanoids demonstrates, in stimulating antioxidant activity due to presence of polyphenolic compounds, possessing health benefits. Flavanoids are considered to be cardioprotectors against antitumor agent because of high ability to transfer electrons, chelate ferrous ions, and scavenge reactive oxygen species. Thus, flavanoids show its full propensity in prevention and treatment of cardiotoxicity caused by the antitumor agent [47].

\section{e. Oral Health}

Oral infection such as dental caries, teeth loss, periodontal diseases etc. can greatly affect the human health. Dental caries may be caused due to the various infections related to the numerous reasons such as bacterial infections, nutritional deficiencies. There are many growing evidence that the use of green tea and its polyphenol plays a beneficial role in oral health [48]. It is suggested that intake of green tea defend healthy cells from transformation into malignant cells, additionally it also abolish halitosis through modification of odorant sulphur components. Nonetheless, consumption of green tea can be useful in prevention and treatment of oral pathologies [49].

\section{f. Bone Health}

Osteoarthritis is a degenerative disorder with little or less curative treatment. Nutritive approach has proven to be useful in maintenance and joint integrity and or health. Many researchers found that oral joint supplements work as anti-inflammatory agent acting as building block for the formation and maintenance of 
Table 2: Commercially Available Nutritional Products $[54,55,56,57]$

\begin{tabular}{|c|c|c|c|c|c|c|}
\hline S. No. & Product & Source & Category & Ingredient & Benefit & Manufacturer \\
\hline 1. & Glucon-D & $\begin{array}{l}\text { Fortified } \\
\text { glucose }\end{array}$ & $\begin{array}{c}\text { Energy } \\
\text { supplement }\end{array}$ & Glucose & $\begin{array}{l}\text { Provide instant } \\
\text { energy \& } \\
\text { rejuvenation }\end{array}$ & Heinz \\
\hline 2. & Glucose-D & $\begin{array}{l}\text { Fortified } \\
\text { glucose }\end{array}$ & $\begin{array}{c}\text { Energy } \\
\text { supplement }\end{array}$ & $\begin{array}{c}\text { Dextrose monohydrate, } \\
\text { Calcium phosphates, } \\
\text { Vitamin D }\end{array}$ & $\begin{array}{l}\text { Provide instant } \\
\text { energy \& } \\
\text { rejuvenation }\end{array}$ & Dabur \\
\hline 3. & Proteinex & - & $\begin{array}{l}\text { Protein and } \\
\text { nutritional } \\
\text { supplement }\end{array}$ & $\begin{array}{c}\text { Essential vitamins, } \\
\text { minerals, protein } \\
\text { hydrolysate, sugar, malt } \\
\text { extract }\end{array}$ & $\begin{array}{l}\text { Supports healthy } \\
\text { physical and } \\
\text { mental growth }\end{array}$ & Pfizer Ltd. \\
\hline 4. & GRD & - & $\begin{array}{l}\text { nutritional } \\
\text { supplement }\end{array}$ & $\begin{array}{l}\text { Vitamins, carbohydrate, } \\
\text { protein }\end{array}$ & $\begin{array}{l}\text { Helps in faster } \\
\text { tissue growth and } \\
\text { repair }\end{array}$ & Zydus \\
\hline 5. & B-Protein & - & $\begin{array}{l}\text { nutritional } \\
\text { supplement }\end{array}$ & $\begin{array}{l}\text { Protein, soy, whey and } \\
\text { casein, essential } \\
\text { vitamins and minerals }\end{array}$ & $\begin{array}{l}\text { nutritional } \\
\text { supplement as } \\
\text { well as aid in the } \\
\text { formation of } \\
\text { haemoglobin }\end{array}$ & British Biologicals \\
\hline 6. & Tropicana & Vitamin C & Energy drinks & $\begin{array}{l}\text { B-vitamin, thiamine, } \\
\text { folate }\end{array}$ & $\begin{array}{l}\text { Nutrient rich juice } \\
\text { and good source } \\
\text { for heart health }\end{array}$ & $\begin{array}{l}\text { Tropicana products, } \\
\text { Inc. }\end{array}$ \\
\hline 7. & Frooti & mango & Energy drinks & $\begin{array}{l}\text { Water, mango pulp, } \\
\text { sugar, anti-oxidant }\end{array}$ & Refreshing juice & Parle Agro. Pvt. Itd. \\
\hline 8. & Abcor & - & $\begin{array}{c}\text { Heart } \\
\text { supplement }\end{array}$ & - & $\begin{array}{l}\text { Lowers } \\
\text { cholesterol }\end{array}$ & Nutri Pharma \\
\hline 9. & Cod liver oil & Fish & $\begin{array}{l}\text { Vitamin and } \\
\text { mineral } \\
\text { supplement }\end{array}$ & $\begin{array}{c}\text { Omega 3fatty acids, } \\
\text { vitamin } A, D\end{array}$ & $\begin{array}{l}\text { Improves } \\
\text { Immunity }\end{array}$ & Sanofi \\
\hline 10. & Fish oil plus & Salmon & $\begin{array}{c}\text { Brain } \\
\text { supplement }\end{array}$ & Omega 3 fatty acids & $\begin{array}{l}\text { reduce risk of } \\
\text { heart disease, } \\
\text { maintains healthy } \\
\text { cholesterol and } \\
\text { blood pressure }\end{array}$ & Pacific Health Inc. \\
\hline 11. & $\begin{array}{l}\text { Calcium plus } \\
\text { milk }\end{array}$ & Fortified milk & $\begin{array}{c}\text { Energy } \\
\text { supplement }\end{array}$ & $\begin{array}{c}\text { Carbohydrate, vitamin } \\
\text { D, calcium }\end{array}$ & $\begin{array}{l}\text { Lower risk of } \\
\text { osteoporosis }\end{array}$ & Shamrock Farms \\
\hline 12. & Cognisure & $\begin{array}{l}\text { Protein-rich } \\
\text { polypepti de } \\
\text { complex }\end{array}$ & $\begin{array}{c}\text { Protein } \\
\text { supplement }\end{array}$ & $\begin{array}{c}\text { Proline-Rich } \\
\text { Polypeptide Complex } \\
\text { (from colostrum), } \\
\text { Fructose, sorbitol }\end{array}$ & $\begin{array}{l}\text { Supports healthy } \\
\text { aging of brain for } \\
\text { alzheimer's } \\
\text { disease }\end{array}$ & Metagenics Inc. \\
\hline 13. & Phenorex & Orange & $\begin{array}{c}\text { Health } \\
\text { supplement }\end{array}$ & $\begin{array}{c}\text { Carnipure, } \\
\text { falcate extract, } \\
\text { Caffeine, } \\
\text { Advantra Z citrus } \\
\text { aurantium extract }\end{array}$ & Burn fat & Gaspari Nutrition \\
\hline 14. & Vectomega & Salmon & $\begin{array}{c}\text { Dietary } \\
\text { supplement }\end{array}$ & Omega 3 fatty acids & $\begin{array}{l}\text { Enhance the } \\
\text { absorption of } \\
\text { omega-3 }\end{array}$ & Europharma \\
\hline 15. & $\begin{array}{c}\text { Collagen } \\
\text { enhance chews }\end{array}$ & $\begin{array}{l}\text { Red wine from } \\
\text { grapes }\end{array}$ & $\begin{array}{l}\text { Youth activating } \\
\text { supplement }\end{array}$ & $\begin{array}{l}\text { Anti-oxidants, } \\
\text { hyaluronic acid }\end{array}$ & $\begin{array}{l}\text { Age-defying } \\
\text { properties }\end{array}$ & Res Vitále \\
\hline 16. & Pediasure & $\begin{array}{c}\text { Natural } \\
\text { supplement }\end{array}$ & $\begin{array}{l}\text { Nutritional } \\
\text { supplement }\end{array}$ & Protein, vitamins & $\begin{array}{l}\text { Help the kids to } \\
\text { grow }\end{array}$ & Abott Nutrition \\
\hline 17. & Revital & - & $\begin{array}{l}\text { Daily health } \\
\text { supplement }\end{array}$ & $\begin{array}{l}\text { Ginseng, vitamin and } \\
\text { mineral }\end{array}$ & $\begin{array}{l}\text { Fight fatigue and } \\
\text { keep you } \\
\text { energetic, } \\
\text { improve health } \\
\text { and immunity }\end{array}$ & Ranbaxy \\
\hline
\end{tabular}


(Table 2). Continued.

\begin{tabular}{|c|c|c|c|c|c|c|}
\hline S. No. & Product & Source & Category & Ingredient & Benefit & Manufacturer \\
\hline 18. & $\begin{array}{l}\text { Threptin } \\
\text { diskettes }\end{array}$ & - & $\begin{array}{l}\text { Protein } \\
\text { supplement }\end{array}$ & Protein and vitamin B & $\begin{array}{l}\text { offering the right } \\
\text { amount of } \\
\text { nutrients, } \\
\text { especially Protein } \\
\text { to the growing } \\
\text { child }\end{array}$ & $\begin{array}{l}\text { Raptakos, Brett\&Co. } \\
\text { Itd }\end{array}$ \\
\hline 20. & Weight smart & - & $\begin{array}{l}\text { Nutritional } \\
\text { supplement }\end{array}$ & $\begin{array}{l}\text { Vitamin and trace } \\
\text { elements }\end{array}$ & $\begin{array}{c}\text { maintain a healthy } \\
\text { metabolism and } \\
\text { Aid proper muscle } \\
\text { function }\end{array}$ & Bayer Corporation \\
\hline
\end{tabular}

normal joint cartilage. It has been established that oral joint supplements contains chondroitin sulphate and/or glucosamine. From the experimental evidence, witnessed that nutraceuticals are capable of promoting or improving cartilage health, when it reaches to the joint through the blood stream demonstrating effective improvement and management in the osteoarthritis/joint health [50].

\section{g. Obesity}

Obesity is deposition of unhealthy amount of body fat associated with various risk factors such as hypertension, diabetes, reduced fertility etc. The major cause of obesity is increased consumption of energy rich foods [51]. Thus, many health practioners are seeking help for nutraceutical interventions on the large basis as potential treatments for obesity and weight management. Nutraceutical like glucomannan, chitosan, fenugreek, $G$ sylvestre, and vitamin $C$ have significantly reduced fat and body-weight in obese individuals and thus, possessing potential anti-obese properties [52].

\section{h. Migraine}

Clinically few recommended nutraceuticals utilized in attacks of migraine such as feverfew, Petasites, Coenzyme Q10 etc. In this feverfew (Tanacetum parthenium) is a species of dried chrysanthemum leaves, majorly constitute melatonin and an essential oil, chrysanthenyl acetate. These constituents reported significantly in preventing attacks of migraine.
Regardless of lack of evidence, the European Scientific Cooperative on Phytotherapy (ESCOP) also recommends the use of feverfew in prophylaxis of migraine. Additionally, Petasites hybridus, known commonly as butterbur also found to be safe and effective for longterm use in management of migraine [53].

\section{Some Marketed Products Available as Nutraceuticals}

Many pharmaceutical companies are attempting to manufacture nutraceuticals in therapeutic areas. Some of the commercially available nutraceuticals are discussed in Table 2.

\section{CURRENT AND FUTURE DEVELOPMENT}

Nutraceutical presents one of the most exciting areas for health innovation, offering inexpensive, safe and effective results for the today's most challenging health problem. Full potential of the functional foods will not be achieved until unless further extensive research is made to ensure safety and efficacy of these products. The main focus for the research is required to meet the scientific standards for efficacy, which is substantial investment. Scientific literature reports daily insights onto the role of existing nutrients, advances on the bioactive compounds and their health benefits. In addition, continued basic and applied nutritional research must pursue a more precise understanding of the mechanisms of action for known nutrients. However, individual, industry, health professional, governments need to adapt new resolution to achieve its full potential. 


\section{CONCLUSION}

Nutraceutical are the bioactive compounds providing the essential beneficial effects beyond the basic nutrition. These are mainly isolated from the nutrients, genetically engineered foods or processed foods. Moreover, these are less expensive, easier to develop and distribute. Nutraceuticals are offering attractiveness not only to the food companies but also to the both pharmaceutical and biotechnology firms. Here, we have gathered several studies highlighting the effectiveness of nutraceutical in management of various diseases such as cancer, diabetes, dry eye disease or prevention and treatment related to the joint health. There are some pharmaceutical companies such as Ranbaxy, Abott healthcare groups providing wide range of nutraceutical utilized in variety of effects. Further, investigation is needed regarding the safety and efficacy of the nutraceuticals. However, there is needed a big battle to won by the pharmaceutical companies as whole, concentrating on nutrition as core component both by the consumers as well as health professionals for prevention and treatment of disease and live longer and healthier lives.

\section{CONFLICT OF INTEREST}

It is hereby declared that the authors do not have any conflict of interest.

\section{ACKNOWLEDGEMENT}

The authors are very thankful to the Department of Pharmacy, School of Medical and Allied Sciences, Galgotias University, Greater Noida and NISCAIR (National Institute of Science Communication and Information Resources), New Delhi, India for providing library facilities in the completion of this manuscript.

\section{REFERENCES}

[1] Aruoma OI. The impact of food regulation on the food supply chain. Toxicology 2006; 221: 119-127. http://dx.doi.org/10.1016/j.tox.2005.12.024

[2] Gil Hardy. Nutraceuticals and functional foods: introduction and meaning. Nutrition 2000; 16 (7-8): 688-689.

http://dx.doi.org/10.1016/S0899-9007(00)00332-4

[3] Amin AR, Kucuk O, Khuri FR, et al. Perspectives for cancer prevention with natural compounds. J Clin Oncol 2009; 27: 2712-25.

http://dx.doi.org/10.1200/JCO.2008.20.6235

[4] US Congress. 100th Congress Orphan Drug Act Amendment, Part II; Federal Food Drug and Cosmetics Act, Washington, D.C. 1988; pp. 100-290;

[5] Wyse R. Health economics and biotechnology drug development. J Biotech Healthcare 1997; 3: 363.

[6] Whitman M. Understanding the perceived need for complementary and alternative nutraceuticals: lifestyle issues. Clin J Oncol Nurs 2001; 5: 190-194.
[7] Kalra EK. Nutraceutical - Definition and introduction. AAPS Pharm Sci 2003; 5:1-2. http://dx.doi.org/10.1208/ps050325

[8] Espín JC, García-Conesa MT, Tomás-Barberán FA Nutraceuticals: facts and fiction. Phytochemistry 2007; 68 : 2986-3008

http://dx.doi.org/10.1016/j.phytochem.2007.09.014

[9] Singh J, Sinha S. Classification, Regulatory acts and applications of nutraceuticals for health. IJPBS 2012; 2(1): 177-187.

[10] Pietro S, Matteo C, Maria M, Pietro AM, Maria LM, Salvatore $\mathrm{N}$, et al. Nutraceuticals and dyslipidaemia: Beyond the common therapeutics. Journal of Functional Foods 2014; 6 : 11-32.

http://dx.doi.org/10.1016/j.jff.2013.12.006

[11] Mendiola JA, Torres CF, Martín-Álvarez PJ, Santoyo S Arredondo BO, Se norans FJ, et al. Use of supercritical $\mathrm{CO} 2$ to obtain extracts with antimicrobial activity from Chaetoceros muelleri microalga. A correlation with their lipidic content. Eur Food Res Technol 2007; 224: 505-510. http://dx.doi.org/10.1007/s00217-006-0353-6

[12] Casado B, Affolter M, Kussmann M. OMICS-rooted studies of milk proteins, oligosaccharides and lipids. J Proteomics 2009; 73: 196-208

http://dx.doi.org/10.1016/j.jprot.2009.09.018

[13] Vazquez L, Torres CF, Fornari T, et al. Recovery of squalene from vegetable oil sources using counter current supercritical carbon-dioxide extraction. J Supercrit Fluids 2007; 40: 59-66. http://dx.doi.org/10.1016/j.supflu.2006.04.012

[14] Verardo V, Bendini A, Cerretani L, et al. Capillary gas chromatography analysis of lipid composition and evaluation of phenolic compounds by micellar electrokinetic chromatography in Italian walnut (Juglans Regia L.): irrigation and fertilization influence. J Food Quality 2009; 32: 262-281.

http://dx.doi.org/10.1111/j.1745-4557.2009.00249.x

[15] Lacomba R, Salcedo J, Alegria A, et al. Determination of sialic acid and gangliosides in biological samples and dairy products: a review. J Pharmaceut Biomed 2010; 51: 346357.

http://dx.doi.org/10.1016/j.jpba.2009.04.023

[16] Dernovics M, Giusti P, Lobinski R. ICP-MS-assisted nano HPLC-electrospray Q/time-of-flight MS/MS selenopeptide mapping in Brazil nuts. J Anal At Spectrom. 2007; 22: 41-50. http://dx.doi.org/10.1039/B608041C

[17] Beaulieu L, Thibodeau J, Bryl P, et al. Proteolytic processing of herring (Clupea harengus): biochemical and nutritional characterisation of hydrolysates. Int J Food Sci Technol 2009; 44: 2113- 2119 .

http://dx.doi.org/10.1111/j.1365-2621.2009.02046.x

[18] Kim SJ, Kawaharada C, Suzuki T, Saito K, Hashimoto N Takigawa $\mathrm{S}$, et al. Effect of natural light periods on rutin, free amino acid and vitamin $\mathrm{C}$ contents in the sprouts of common (Fagopyrum esculentum Moench) and tartary (F. tataricum Gaertn.) buckwheats. Food Sci Technol Res 2006; 12: 199205.

http://dx.doi.org/10.3136/fstr.12.199

[19] Guclu-Ustunda g O, Mazza G. Extraction of saponins and cyclopeptides from cow cockle seed with pressurized low polarity water. Food Sci Technol 2008; 41: 1600-1606.

[20] Zanes Furlani RP, Teixeira GH. Vitamins B1, B2 contents in cultivated mushrooms. Food Chem 2008; 106: 816-819. http://dx.doi.org/10.1016/i.foodchem.2007.06.007

[21] Anwar F, Przybylski R, Rudzinska M, et al. Fatty acid tocopherol and sterol compositions of Canadian prairie fruit seed lipids. J Am Oil Chem Soc 2008; 85: 953-959. http://dx.doi.org/10.1007/s11746-008-1276-0

[22] Bakowska-Barczak AM, Schieber A, Kolodziejczyk P Characterization of Canadian black currant (Ribes nigrum L.) 
seed oils and residues. J Agric Food Chem 2009; 57: 1152811536.

http://dx.doi.org/10.1021/jf902161k

[23] Kim WJ, Kim J, Veriansyah B, Kim JD, Lee YW, Oh SG, et al. Extraction of bioactive components from Centella asiatica using subcritical water. J Supercrit Fluid 2009; 48: 211-216. http://dx.doi.org/10.1016/j.supflu.2008.11.007

[24] Naviglio D, Caruso T, lannece $P$, et al. Characterization of high purity lycopene from tomato wastes using a new pressurized extraction approach. J Agric Food Chem 2008; 56: $6227-6231$

http://dx.doi.org/10.1021/jf703788c

[25] D'Antuono LF, Elementi S, Neri R. Glucosinolates in Diplotaxis and Eruca leaves: diversity, taxonomic relations and applied aspects. Phytochemistry 2008; 69: 187-199. http://dx.doi.org/10.1016/j.phytochem.2007.06.019

[26] Brady K, Ho CT, Rosen RT, et al. Effects of processing on the nutraceutical profile of quinoa. Food Chem 2007; 100: 1209-1216.

http://dx.doi.org/10.1016/j.foodchem.2005.12.001

[27] Montañes F, Olano A, Reglero G, et al. Supercritical technology as an alternative to fractionate prebiotic galactooligosaccharides. Sep Purif Technol 2009; 66: 383-389.

[28] Li S, Lo CY, Ho CT. Hydroxylated polymethoxyflavones and methylated flavonoids in sweet orange (Citrus sinensis) peel. J Agric Food Chem 2006; 54: 4176-4185. http://dx.doi.org/10.1021/jf060234n

[29] Chatterjee S, Niaz Z, Gautam S, et al. Antioxidant activity of some phenolic constituents from green pepper (Piper nigrum L.) and fresh nutmeg mace (Myristica fragrans). Food Chem 2007; 101: 515-523.

http://dx.doi.org/10.1016/j.foodchem.2006.02.008

[30] Sharma UK, Sharma N, Gupta AP, et al. RP-HPTLC densitometric determination and validation of vanillin and related phenolic compounds in accelerated solvent extract of Vanilla plantifolia. J Sep Sci 2007; 30: 3174-3180.

http://dx.doi.org/10.1002/jssc.200700229

[31] Shadkami F, Estevez S, Helleur R. Analysis of catechins and condensed tannins by thermally assisted hydrolysis/methylation-GC/MS and by a novel two step methylation. J Anal Appl Pyrolysis 2009; 85: 54-65. http://dx.doi.org/10.1016/j.jaap.2008.09.001

[32] Chi L, Li Z, Dong S, et al. Simultaneous determination of flavonoids and phenolic acids in Chinese herbal tea by betacyclodextrin based capillary zone electrophoresis. Microchimica Acta 2009; 167: 179-185. http://dx.doi.org/10.1007/s00604-009-0229-0

[33] Chung JY, Choo JH, Lee MH, et al. Anticariogenic activity of macelignan isolated from Myristica fragrans (nutmeg) against Streptococcus mutans. Phytomedicine 2006; 13: 261-266. http://dx.doi.org/10.1016/i.phymed.2004.04.007

[34] Gonzalez-Montelongo R, Lobo MG, Gonzalez M. Antioxidant activity in banana peel extracts: testing extraction conditions and related bioactive compounds. Food Chem 2010; 119: 1030-1039.

http://dx.doi.org/10.1016/j.foodchem.2009.08.012

[35] Chirinos R, Campos D, Betalleluz I, Giusti MM, Schwartz SJ, Tian $Q$, et al. High-performance liquid chromatography with photodiode array detection (HPLC-DAD)/HPLC-mass spectrometry (MS) profiling of anthocyanins from and ean mashua tubers (Tropaeolum tuberosum Ruiz and Pavon) and their contribution to the overall antioxidant activity. J Agric Food Chem 2006; 54: 7089-7097. http://dx.doi.org/10.1021/jf0614140

[36] Green CE, Hibbert SL, Bailey-Shaw YA, et al. Extraction, processing and storage effects on curcuminoids and oleoresin yields from Curcuma longa L. grown in Jamaica. J. Agric Food Chem 2008; 56: 3664-3670.

http://dx.doi.org/10.1021/jf073105v
[37] Barbero GF, Liazid A, Palma M, et al. Ultrasound-assisted extraction of capsaicinoids from peppers. Talanta 2008; 75 : $1332-1337$

http://dx.doi.org/10.1016/j.talanta.2008.01.046

[38] Sivakumar G, Aliboni A, Bacchetta L. HPLC screening of anti-cancer sulforaphane from important European Brassica species. Food Chem 2007; 104: 1761-1764.

http://dx.doi.org/10.1016/j.foodchem.2006.11.040

[39] Chairote EO, Chairote G, Niamsup H, et al. The presence and the content of Monacolins in Red Yeast rice prepared from Thai glutinous rice. World J Microbiol Biotechnol 2008; 24: 3039-3047. http://dx.doi.org/10.1007/s11274-008-9850-z

[40] Kanu PJ, Zhu KR, Kanu JB, et al. Biologically active components and nutraceuticals in sesame and related products: a review and prospect. Trends Food Sci Tech 2007; 18: 599-608. http://dx.doi.org/10.1016/j.tifs.2007.06.002

[41] Badimon L, Vilahur G, Padro T. Nutraceuticals and atherosclerosis, human trials. Cardiovasc Therap 2010; 28: 202-215.

http://dx.doi.org/10.1111/j.1755-5922.2010.00189.x

[42] Nair HB, Sung B, Yadav VR, et al. Delivery of antiinflammatory nutraceuticals by nanoparticles for the prevention and treatment of cancer. Biochemical Pharmacology 2010; 80: 1833-1843. http://dx.doi.org/10.1016/j.bcp.2010.07.021

[43] Zhou XJ, Hu XM, Yi YM, et al. Preparation and body distribution of freezedried powder of ursolic acid phospholipid nanoparticles. Drug Dev Ind Pharm 2009; 35: 305-10. http://dx.doi.org/10.1080/03639040802302165

[44] Jalbert I. Diet, nutraceuticals and the tear film. Experimental Eye Research 2013; 117: 138-146. http://dx.doi.org/10.1016/j.exer.2013.08.016

[45] Aruoma OI, Landes B, Ramful-Baboolall D, Bourdon E, Neergheen-Bhujun $\mathrm{V}$, Wagner $\mathrm{KH}$, et al. Functional benefits of citrus fruits in the management of diabetes. Prev Med 2012; 54: 12-16.

http://dx.doi.org/10.1016/j.ypmed.2012.02.012

[46] Bahadoran Z, Mirmiran P, Azizi F. Dietary polyphenols as potential nutraceuticals in management of diabetes: a review. Journal of Diabetes \& Metabolic Disorders 2013; 12: 43-52. http://dx.doi.org/10.1186/2251-6581-12-43

[47] Kandaswami C, Middleton E. Free radical scavenging and antioxidant activity of plant flavonoids. In: D. Armstrong $2^{\text {nd }}$ Eds. Free radicals in diagnostic medicine 1994; pp. 351-376 (New York: Plenum Press). http://dx.doi.org/10.1007/978-1-4615-1833-4 25

[48] Wu CD, Wei GX. Tea as a functional food for oral health. Nutrition 2002; 18(5): 443-4.

http://dx.doi.org/10.1016/S0899-9007(02)00763-3

[49] Narotzki B, Reznick AZ, Aizenbud D, et al. Green tea: A promising natural product in oral health. Archives of Oral Biology 2012; 57: 429 - 435. http://dx.doi.org/10.1016/j.archoralbio.2011.11.017

[50] Baici A. Analysis of glycosaminoglycans in human serum after oral administration of chondriotin sulphate. Rheumatol Int 1992; 12: 81-88. http://dx.doi.org/10.1007/BF00290259

[51] Rajasekaran A, Sivagnanam G, Xavier R. Nutraceuticals as therapeutic agents: A Review. Research J Pharm and Tech 2008; 1(4): 328-340

[52] Bhowmik D, Gopinath H, Pragati KB, et al. Nutraceutical -A Bright Scope and Opportunity of Indian Healthcare Market. The Pharma Innovation 2013; 1(11): 1-13.

[53] Taylor Frederick R. Lifestyle changes, dietary restrictions and nutraceuticals in migraine prevention. Techniques in Regional Anesthesia and Pain Management 2009; 13: 28-37. http://dx.doi.org/10.1053/j.trap.2009.03.008 
[54] Chaturvedi S, Sharma PK, Garg VK, et al. Role of Nutraceuticals in Health Promotion. International Journal of PharmTech Research 2011; 3 (1): 442-448.

[55] Pandey M, Verma RK, Saraf SA. Nutraceuticals: New era of medicine and health. Asian J Pharm Clin Res 2010; 3: 11-15.
[56] Sarin R, Sharma M, Singh R, et al. Nutraceuticals: A Review. International Research Journal of Pharmacy 2012; 3(4): 9599.

[57] Keservani Raj K, Vyas N, Jain S, et al. Nutraceutical and Functional Food as Future Food: A Review. Der Pharmacia Lettre 2010; 2(1): 106-116. 